\title{
The Celtic connection with southern Africa: Tracing a genealogy of missionary spirituality
}

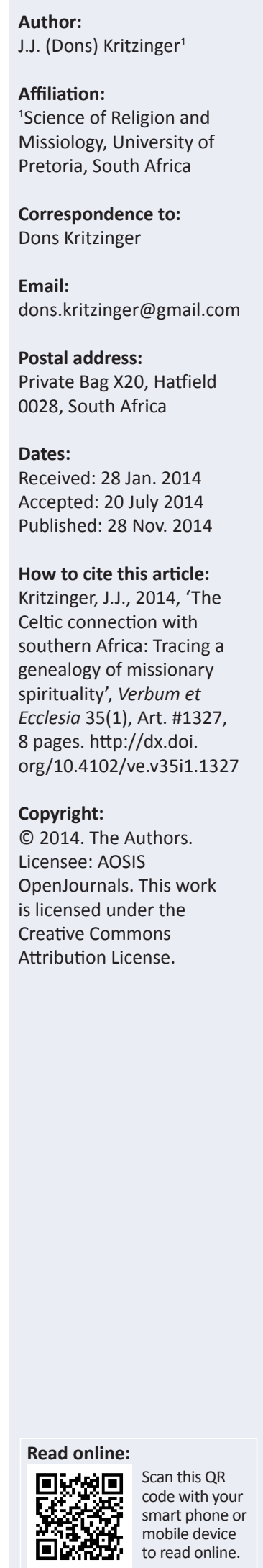

It is quite generally accepted that the missionary monks from the Celtic tradition in Ireland and Scotland played a significant role in the Christianisation of Europe during the Dark Ages. This is a story that should not be forgotten. It is also well known that this was preceded by the thorough evangelisation of Ireland and Scotland (and northeast England) itself by these Celtic monks. What is, however, not getting enough attention is the (much later) outreach to southern Africa coming from those same quarters. In this article an effort is made to give credit to this, and to trace the specific spirituality that made all this possible.

\section{Introduction}

We will first have to get clarity on a few terms that will often be used in this article.

\section{Spirituality}

Spirituality is a concept that is not so easy to define, and is also used in different ways. In the Christian context 'spiritual' can be used for a person animated by God, and driven by the Holy Spirit. In the history of the church 'the spiritual' also came to mean the territory of the clergy, different from that of the 'laity'. In more modern times - under the influence of revivals and renewal movements - it came to denote the Christian who has a 'deeper' quality of commitment and prayer life, with a mystical touch to it. In general religious language we can say that 'spiritual' refers to the mental aspect of life, over against the material and sensual.

It is understandable that the term is often misunderstood. We tend to call some people 'spiritual' when we regard them as very dedicated to God. Often it means that such people are 'so heavenly minded that they are of no earthly good', as someone said. 'Spirituality' is often frowned upon as a lifestyle that sees life in this world as an unfortunate stage that we must go through, but our focus should be on our final destination, heaven. However, this is far too narrow an understanding.

We must acknowledge that there are many types of spirituality. It not only applies to Christianity, but also to other religions. As a matter of fact, the Eastern spirituality became very attractive to Westerners who felt that the prevalent secular materialism robbed them of the awareness of the transcendent. The so called New Age movement fostered a specific kind of spirituality.

But we can go further. Even within the Christian tradition we can speak (in a generalised way) of (for instance) Catholic spirituality, as opposed to (typical) Reformed spirituality. Then there is the Pentecostal or charismatic spirituality. Each of the Catholic orders, and the different Protestant denominations, have their own unique spirituality. So we can even speak of German and (this will happen quite often in this article) Celtic spirituality. By this we would mean, then, a kind of personality, a typical approach regarding religious or 'spiritual' matters.

\section{Missionary spirituality}

We want to explore the concept of 'missionary spirituality' in this article. David Bosch in his Spirituality of the Road (1979) deals with this spirituality in his usual lucid way:

'Flesh' and 'spirit' in the Bible do not refer to two segments of our lives, the one outward and worldly, the other inward and otherworldly, as though we are spiritual when we pray and worldly when we work. No, flesh and spirit refer to two modes of existence, two life orientations. Being spiritual means being in Christ, whether we pray or walk or work. Spirituality is not contemplation over against action. It is not a flight from the world over against involvement in the world.... The involvement in this world should lead to a deepening of our relationship with and dependence on God, and the deepening of this relationship should lead to increasing involvement in the world ... (p. 13) 
During the nineteen seventies and eighties there was an animated debate in ecumenical and, especially, evangelical circles about the viewpoint that the propagation of the gospel and the socio-political involvement in the world should be clearly distinguished, and one or the other prioritised. In Bosch's opinion these two aspects belong intimately together as interrelated aspects of the missionary paradigm. He acknowledged that especially Protestants 'have grown up in a tradition which has tended to view God and man as competitors for our love and devotion' (Bosch 1979:14), with the result that we felt that a choice was necessary. Or, put differently:

We seem to remain Monophysites, of one type or the other; previously we recognized only the divine in Christ, now we see only the human. Where spirituality used to be defined exclusively as a flight from the world, it is now being defined exclusively as involvement in the world. Where church and world used to be neatly distinguished one from the other, there is now a complete absence of any tension between church and world ... (Bosch 1979:15)

As an exercise in mission history this article will try to trace a specific kind of missionary spirituality through different ages and in different settings. The spirituality we hope to illustrate is that of a very robust, down to earth kind which everywhere made a strong impression on society.

\section{The Celts}

This is not a study on the Celts. An in-depth description of the history and culture of this interesting ethno-linguistic group is outside the bounds of this article. However, a generalised overview, gleaned from a variety of literature on them, is necessary as background to what follows.

The Celts could already be identified as an ethno-linguistic group of tribal societies in the Iron Age, some 6 centuries before Christ, and before the Greeks and Romans became dominant in their part of the world. Their stronghold was in central Europe, but the extent of their range was much wider. In Medieval times these peoples, who spoke Celtic languages, could especially be found in the northern reaches of mainland Europe and on the (later) British Isles. To the Romans, they were the Gauls. By the 6th century AD the Celtic languages were not widely used on the continent any more, but on the northern islands they remained identifiable up to a much later time. As a matter of fact, in Ireland, Scotland, Wales, Cornwall, Isle of Man and Brittany these languages are presently undergoing a kind of revival, and in some places are acknowledged as official languages.

These Celtic tribes were led by kings. They were warlike people, but seem to have also had an intellectual class of poets, jurists and religious figures called druids. These priests carried out the religious rites and sacrifices, but were also the people who were the custodians of traditions and folklore. They were very important in the functioning of the community, and acted also as judges and teachers. The Celts worshipped many gods, corresponding to the various needs of the communities. Most were basically family gods, but some attained popularity across tribal barriers. The gods were male and female, and often functioned in threes. Shrines to the gods were erected especially on remote hilltops, or in groves and at lakes.

The extent of the Celtic advance into always new territory indicated a kind of mobility that was exceptional. They were not so much known as conquerors who established large kingdoms, but rather as immigrant peoples, mingling with the indigenous peoples, and in the end putting their stamp on the culture of the area.

\section{The development of a Celtic Christian spirituality St Patrick of Hibernia}

St Patrick is generally regarded as the founder of Christianity in Ireland. However, being a very early figure, myth and history flow together in the traditions around his life story. Very little was written by himself or contemporaries.

Bavinck (1948:86) places his birth around the year 389, somewhere in England or Wales (Cahill 1995:105). He seems to have been born into a Christian family. His carefree youth was however cut short when he was taken into slavery through a raid of an Irish chieftain, Miliucc, from the region of the Antrim hills (Cahill 1995:101). He was then about 16 years of age. For 6 years he led a lonely life full of hardship whilst tending the sheep of his master. However, as Cahill puts it (1995):

Patricius endured six years of this woeful isolation, and by the end of it he has grown from a careless boy to something he would surely never otherwise have become - a holy man, indeed a visionary for whom there was no longer any rigid separation between this world and the next ... (p. 102)

He had a dream in which he was directed to the sea, where a ship would be waiting for him. He followed the instructions and indeed found a ship which he boarded. This ship took him to the European continent where he wandered around for a few years. Tradition has it that he visited France (Gaul), even reaching Italy and further east before he went back to his home and family where he thought he would stay the rest of his life.

However, he had a second dream which changed his life. In the dream or vision he saw a man who handed him a letter: 'We beg you to come and walk among us once more' (Cahill 1995:105). This became a real calling to him, but before he went back to Ireland he spent time at the monastery of Lerins on an island near (the present) Cannes in the Mediterranean. Here he was eventually ordained as bishop for Ireland (Hibernia) ... 'virtually the first missionary bishop in history' according to Cahill (1995:107). What was significant was that he really seems to be the first missionary we know of to go beyond the reach of the Roman empire and Roman law.

Patrick was clearly a good and brave man whose integrity made a favourite impression on the rough Irish. He 
concentrated on the leaders, the tribal chiefs, in order to win whole tribes for Christ (Bavinck 1948:88). But Cahill (1995:109) mentions that his love for his adopted people shines through his writings ... He worries constantly for his people, not just for their spiritual but for their physical welfare ...'. No wonder, then, that he succeeded in a remarkable way. At the end of his three decades of ministry on the island he could see around him transformed communities. Violence decreased, and the slave trade - which he experienced firsthand, and against which he spoke out - came to a halt.

In one or other way Patrick succeeded to wed his faith with the Irish spirit. He became an Irishman. Irish Christianity was indigenous, maybe the first 'de-Romanised Christianity in human history' (Cahill 1995:148), without the GrecoRoman political and cultural baggage. And that could be the secret of its longevity. Patrick gave the robust Irish, with their virtues of loyalty, courage and generosity, new values to die for: faith, hope and charity.

He could not have done this alone. Whilst he unceasingly travelled all over the country to evangelise the people, stopping at every tribal village to preach, he also motivated scores of young men to join him in his work. His method was to establish indigenous monasteries everywhere. From here his disciples tirelessly continued with the Christianisation of the tribes. The church in Ireland was centred on monasteries and their monks, and not structured around bishops another unique aspect of this Christianity. And, unique amongst the northern peoples, the faith was introduced and accepted without bloodshed.

\section{Columcille (St Columba) of Iona}

In time the Irish developed an independent Christianity that could be described (like Bavinck [1948:92-93] did) with four main characteristics:

- the movement of a whole people towards the Christian faith

- an indigenous process of accommodating much of the traditional spirituality, its places and rituals

- the love of and respect for learning and books

- a Christian church organised around monks and monasteries.

It is not clear how the third characteristic developed, because it was maybe this more than any other that set them apart from the situation on the mainland.

A fifth characteristic can also be picked up from various commentators: the Celtic love for 'peregrinatio' (travel, roaming), coupled with a missionary zeal and piety, which made them special candidates to go out in an Abrahamic way to where God would lead them (see Bavinck 1948:88).

It was this context into which was born a prince of Clan Conaill, born in the royal enclosure of Gartan, on December 07, 521, less than 90 years after Patrick's arrival as bishop (Cahill 1995:169). He could have become a king, maybe even high king, it was said, and he was as such educated in the bardic tradition. But Crimthann (or Fox) chose to become a monk, and chose Columcille, or Dove of the Church, as his later monastic nickname. This was Romanised as Columba. As monk he received further Christian learning and made contact with the Benedictine monastic rules.

Columba had a forceful personality, and became a founder of monasteries. It is said that he founded 41 monasteries before he turned 41 in the year 562. And in these monasteries manuscripts were furiously being copied. In a strange sequence he made battle with the king over a Psalter manuscript which his monks copied, but the king wanted back. In this battle the monks routed the king, and 3001 people were killed. Columba was excommunicated in 564 because he took up arms:

His penance was permanent exile from his beloved Ireland: he must now reach heaven by a voyage of no return, and in his exile he must save as many souls as in the battle he precipitated ... (Cahill 1995:171).

He set out with twelve companions to the island of $\mathrm{Hy}$, or Iona, on the west coast of Scotland, just far enough north so that he could never have a view of Ireland. The purpose of the foundation was therefore evangelistic: Columba was called to bring many people (at least 3001!) to faith in the gospel. Through this small beginning Columba eventually became the apostle of Scotland, reaching out to the still heathen Picts and Scots of the north.

The monastic tradition of Ireland provided the basic plan for the monastery at Iona: a hut for each monk, a refectory and kitchen, a scriptorium and library, a smithy, a kiln, a mill, and a couple of barns, and a modest church ... nothing fancy. But soon it became necessary to also build quarters for the growing number of visitors and monks who came to stay, attracted by the reputation of this larger-than-life abbot of Iona. From Iona Columba founded scores of new monasteries, each connected to the mother house at Iona. When the number of monks at Iona reached 150 he would send out ' 12 and one' to found a new monastery in a new setting, closer to the people to be reached.

When he died in 597 - his quota of 3001 souls saved long ago passed - he left behind him a legacy of simple and real sanctity. And that was not the end. His spiritual sons maybe the greatest of whom was Aidan, the founder of the monastery Lindisfarne on the Northumbrian north coast of England - would continue to evangelise the Picts and Scots of Scotland, and to establish literate Christian societies amongst them. And from Lindisfarne ('Holy Island') the movement would continue south to the heathen Angle kingdoms of Britain.

\section{Columbanus}

The Celtic monks did not only follow Columba to the north. There was also an energetic movement southwards which reached deep into Europe. We need only mention one of these missionaries: Columbanus, a younger contemporary of Columba. Around 590 he departed to Gaul, where he 
commenced to found monasteries. These monks were afraid of nothing, and were willing to work under the most difficult of situations as so-called 'green martyrs'. Cahill (1995:192) remarks that it is unsure exactly how many monasteries were founded in Columbanus's name during his lifetime and after his death, but the number would not be less than 60 and may be more than 100 .

As was already said before, this movement of Celtic spirituality and love for books and learning made a huge difference in the darkened Europe after the squashing of the Greco-Roman civilisation by the barbarians.

In an interesting turn of history, it was another monk, this time from a Benedictine monastery and not an Irish one, one who became Pope Gregory (the Great), that also initiated a missionary outreach to the Angles by sending Augustine to Britain in 596 (Neill 1964:58). Eventually this Roman thrust would (at the Whitby synod of 664) take the upper hand in Northumbria (Bosch 1991:235), but the two traditions would together have a lasting influence on Western culture.

\section{A typical spirituality?}

Can one from the above derive an outline of the typical missionary spirituality of these medieval Celtic missionaries? A few descriptive words do come to mind: (1) a certain independence of operation, but (2) with a simple piety of mind and an integrity of purpose, (3) a willingness to venture out in faith, (4) a tendency not to settle but a daring to move on to reach the unreached. And furthermore (5) the pervading love of books and learning. (6) Through their efforts they had in mind the total transformation of people, the establishment of a Christian tribe and the healing of a whole context.

\section{The southern African connection}

Without implying that all Scots were or are Celts, it can be accepted that not only does Celtic blood run in the veins of the Scottish population, but it can be argued that also much of the old Celtic spirit can be found in the traditional Scots.

When turning to the southern African mission field of the 19th century I would therefore like to draw attention to (only) three Scottish initiatives: the first would be the work of the well-known David Livingstone, the second the Murray family of Scotsmen turned Dutch Reformed pastors, and the third will be the achievement of the Scots Presbyterians at Lovedale in the Eastern Cape province of South Africa.

\section{David Livingstone}

Robert Moffat was a pioneer missionary of the London Missionary Society. He established an influential mission station at Kuruman, far into the interior of south-western Africa. In 1841 he was joined by a young Scotsman, who would soon become his son-in-law, and would eventually become known all over the British Empire and beyond as the foremost explorer of Africa.
It was David Livingstone's travels of exploration that made him a household name abroad, but in his heart he was - till he came to his end in 1873, deep in Africa, where people found him on his knees as if in prayer - before anything else a missionary (Van den Berg 1965:124). He had a wide view of the missionary task. Even before he went to Africa he wrote in his 'policy document' (Van den Berg 1965):

... to endeavour by every means in his power to make known the Gospel by preaching, exhortation, conversation, instruction of the young; improving, so far as in his power, the temporal condition of those among whom he labours, by introducing the arts and sciences of civilization ... (p. 67)

Is it co-incidence that his approach is in many aspects of the same kind as the missionary spirituality of the early Celtic missionaries exemplified by (amongst others) Patrick, Columba and Columbanus? Or is there a 'genealogical' link? We can systematise the similarities.

(a) He indeed had an independent approach. He could also be called a pragmatist. He did not stay long at Kuruman before he decided to move further and to work independently. He was drawn into his career of exploration and discovery because he was looking for (1) safe and healthy places to establish missions and (2) areas where profitable agriculture and other ventures could be started ... the only way he felt 'this devilish trade in human flesh' (Ransford 1966:69) could be countered. When the mission fraternity became increasingly critical of these kind of ventures he decided (in 1856, whilst visiting London) to rather sever his relationship with the Missionary Society than to terminate this personal calling (Du Plessis [1911] 1965:272).

(b) Livingstone was not always an easy and jovial companion. There were quite a number of people that had serious problems with him. To the Boers of the Transvaal Republic he was persona non grata and was despised as a typical example of those kind of liberal missionaries that drove them from the Cape Colony. He was implicated in gun running and other crimes, which led to his mission station at Kolobeng being destroyed. He also had personal problems with people joining him on expeditions (amongst them the later famous painter Baines). But with the (black) African people he had the best of relations. He won their loyalty and admiration by his simple kindness towards them, as well as his strong faith. He continued to share the good news of the gospel wherever he went, and taking care of his companions, and those they stayed with, by his medical interventions. Van den Berg (1965:64) quotes Hoekendijk who said that he has drawn 'a trail of goodness' through Africa. He won the trust of the African people through 'the magic power of kindness' (Van den Berg 1965:90). Du Plessis wrote in 1911:

Nor are there many finer stories in the recorded deeds of any race, than how Livingstone's black bodyguards, after earnest deliberation on their duty, embalmed his remains and bore them shoulder-high, with all his journals and belongings, a thousand miles to the coast, through hostile tribes, and desolate, difficult country ... (p. 245) 
In this regard it is also not without significance that in a prime spot at the Victoria Falls (named by him) in Zimbabwe there is a larger-than-life statue of David Livingstone. He is still honoured as 'missionary, liberator, explorer' in this part of the world where there is much bitterness over the colonial legacy. Across the river in Zambia is the city still called Livingstone. (Most other colonial names were changed.)

(c) Livingstone ventured out in faith. He had a certain stubbornness which enabled him to keep on when things became very difficult. In the process he even neglected his wife (Mary, the daughter of Robert Moffat) and family. As Ransford (1966) said:

... it was not so much his stamina which drove him across the breadth of Africa as the unwavering belief that he had some special place in God's scheme for the continent ... (p. 77)

He was driven on by this faith and the goal of assisting in establishing God's kingdom and its blessings in Africa.

(d) As missionary he - like his Celtic predecessors - was spurred on by the words of Robert Moffat: 'the vast unoccupied district, where no missionary has ever been' (Horne 1894:232). He was, from the start, more of a pioneer and explorer than a patient and persevering missionary (Du Plessis [1911] 1965:249). Not only did he leave Kuruman at the earliest convenience, but swiftly moved from Mabotsa to the Bakwena (of Sechele), to Kolobeng, Makololo and the Linyanti. And from there he started out on his great voyages across Africa. He was always moving further. When the time came for him (in 1857) to bid farewell to the London Missionary Society that sent him out, it was with these famous words: 'I go back to Africa to try to make an open path for commerce and Christianity' (Van den Berg 1965:66). Although it did not work out as well as he dreamt, he could in his lifetime see the birth of the Universities Mission to Central Africa (UMCA) of the Church of England (1861) reaching out to the people around 'Livingstone's Lake'. After his death the Church of Scotland started the Livingstonia mission to the same area (Cronjé 1948:65-66). His toil to reach the unreached was not in vain. Also the fruitful later outreach of the Church Mission Society to Uganda with the Scot Alexander Mackay as leader was inspired by his explorations (Bavinck 1948:125).

(e) The old Celtic missionaries had a great love of books, and Biblical manuscripts. In this Livingstone would not be much different. One of his treasured possessions, which he always had with him and used constantly, was his tattered Bible. No one can read his many manuscripts, based on painstaking journals, and not be impressed by his learning, writing skills and sharp observations. His well-known three 'C's: Christianity, Commerce and Civilisation (in any order), formulated as his three pronged approach, indicates his high expectations for the civilising influence of his work. He was a child of his time. With hindsight we can criticise his too naïve identification of the gospel (Christianity) and the Victoriantype civilisation - we may think that he somewhat confused the Pax Britannica with the Pax Christi (Van den Berg 1965:89) - but the fact is that Livingstone believed that (Western type) education, literacy and general (Western type) development would benefit and uplift his beloved African people. (f) Today we would regard Livingstone's understanding of mission as 'holistic', 'comprehensive'. It is clear that his understanding was so broad that neither his journeys of exploration nor his commercial nor his civilising dreams were outside his missionary scope. He did not back off from political involvement. He took the side of the Batswana against the Boers, and was willing to involve the British colonialists in order to safeguard them against Boer encroachment (Adonis 1982:51). But the more he travelled the more he became consumed with the passionate war against the slave trade. He called it 'this devilish trade in human flesh' (Ransford 1966:69). On the granite slab covering his grave in Westminster Cathedral, London, are the words which were some of the last he ever wrote: '... May Heaven's rich blessing come down on every one ... who will help to heal this open sore of the world' (Du Plessis [1911] 1965:245). His whole life - and all his efforts - became a crusade against this evil. God destined him to play this role, he believed. It was with great sadness that he came to realise that he has unwittingly opened the roads into Africa not only for Christianity, Commerce and Civilisation, but also for the slave trade (Van den Berg 1965:83)! Not all his well-meant efforts were to the benefit of his African brethren.

There can be no doubt that David Livingstone was one of the most interesting and formidable southern African missionaries of the colonial era. He was not the average nineteenth century missionary who settled in one place (like for example his father-in-law, Robert Moffat), and built up a mission station and a church. It is exactly in his restless, but intense wanderings that he is a child of the old Celtic missionaries. His impact was considerable ... like those of his spiritual forebears in earlier centuries. Although some would regard him more as an explorer than a missionary, there is no doubt that he saw himself above all as a missionary.

\section{Lovedale in the Eastern Cape}

There are two reasons why I include this short section on Lovedale in this article: the first is that we have here another Scottish project into southern Africa, and the second reason is that products of the schools at Lovedale were part of the first group of people to go to Lake Malawi as missionaries of the above mentioned Livingstonia mission brought together in memory of David Livingstone.

In 1824 four missionaries, Brownlee, Thomson, Ross and Bennie (the latter two from the Glasgow Missionary Society, which in 1845 became part of the Free Church of Scotland) (Du Plessis [1911] 1965:188) arrived amongst the Xhosa of the (present) Eastern Cape province of South Africa. Ross and Bennie established the mission - called Lovedale in honour of the secretary of their society (Du Plessis [1911] 1965:184). Right from the beginning one of the main focus points of these missionaries was education and training. It was just natural for these people, who were so clearly aware of what education has done for Scotland, to pass through the benefits to the indigenous people (Du Plessis 1912:52). Very soon a printing press was also supplied to them, and the work of literacy commenced. 
Graham Duncan (2004) rightly criticised their educational approach which had the effect of alienating the people from their past and their culture by aiming to turn them into (Victorian) black gentlemen. He called it 'coercion'. However, it must be understood that the missionaries of those days did not think twice about the kind of education they planned, but just transmitted the best they had to their protégés. And In that regard it must be acknowledged that they had wonderful successes.

Already in 1841 the basic school was supplemented by a training institution for evangelists and teachers, in which the curriculum also included technical training. It was this institution which would eventually develop into the Fort Hare University, the first one in South Africa that especially catered for the indigenous black people. When the time came they were ready to respond to the call of the Livingstonia mission and could supply quite a number of trained members to that team.

\section{The Murrays of the Dutch Reformed Church in South Africa}

At the beginning of the 19th century the 'Cape of Good Hope' became a British colony, and a process commenced to undermine the strong Dutch traditions at the Cape and to put a stronger British stamp on the society. A large contingent of English speakers were brought out in 1820 to settle in the Eastern Cape ... also to act as buffer between the expanding European and Xhosa communities in the east. The Dutch Reformed Church (DRC) (no more the state church, but still under the tutelage of the state) at that stage suffered a shortfall of ministers, so qualified candidates were also sought in Britain. Amongst those who were willing to come to serve in the colony was one Andrew Murray from Aberdeen in Scotland.

Andrew Murray sr (so called because he would have an even better known son with the name of Andrew) became the DRC minister in the frontier town Graaff-Reinet where he served from 1822 to 1865 . From his marriage with Jemima developed a family which played an extra-ordinary role in the church. His five sons (two of which were John, who became the first professor at the Stellenbosch Theological Seminary in 1859, and Andrew jr) all followed in his footsteps as DRC ministers, and four of his daughters married DRC ministers (Crafford 1992:107). By the third generation the contribution was 45 ministers of religion!

In time this Scottish family would become at home in the Dutch speaking community at the Cape (something like their spiritual forebear St Patrick?) and took leadership positions in church and society. Andrew jr (for example) would later on be called to chair the synods of the DRC for not less than six times! Andrew sr likewise from the beginning played a leading role in the early synod meetings of the church (since 1824). One of the issues in which he became involved was the problem of the colour prejudice amongst the (white) church members. He felt very strongly that this had to be broken down. However, being a pragmatist, he realised that this could not be done by mere decisions. He was also deeply worried that the colour prejudices would hinder the spread of the gospel amongst the indigenous population. $\mathrm{He}$ was therefore willing to make compromises, and became responsible for the (often quoted and - with hindsight regrettable) decision taken at the 1857 synod where, in response to questions from other frontier congregations about integrated communion services, it was decided to allow separate communion in some cases, although it was 'not desirable or scriptural'. The reason for the compromise was that 'it would help the furtherance of the gospel among the heathen' (Adonis 1982:56; Crafford 1982:42).

This missionary motif was inbred in this extended family. Without this family it is a question how much of the extensive mission work of the DRC would have come to fruition. Soon a host of missionaries were Murrays, Hofmeyrs, Louws and other direct descendants of the original Murray family. Amongst them were some of the pioneers of DRC missions further north in Africa: AC Murray in Malawi (1889) (son of the second Murray minister of Graaff-Reinet), AA Louw in Mashonaland in Zimbabwe (1891) (whose mother was Jemima Murray), George de Coligny Murray in the Transkei, John Neethling Murray in the Waterberg (1894-1909), Mary Murray in Botswana, John Murray Hofmeyr (son of the sonin-law minister of Somerset-East) in Zambia (1899), Andrew Murray Hofmeyr in Natal and AG Murray in Moçambique (Crafford 1982:108; Cronje 1981:194).

These mission outreaches into Africa would probably never have happened if it was not for the role of the Ministers Missionary Society and the Theological Students Missionary Society in which Murray family members played a significant role (Cronje 1981:7). Another grandson, AF Louw, became the first head of the 'Boeresendinginstituut' in 1902, where ex Boer War prisoners could be prepared for the mission work to which they received a calling during their time in the camps in Sri Lanka and elsewhere (Crafford 1982:274).

Especially noteworthy for our theme is the life and work of Dr Andrew Murray jr (1828-1917). He studied, with his eldest brother John, in Scotland and Holland. Here he had breathed the atmosphere of religious fervour as well as callous unbelief. Although he adhered firmly to the Reformed faith, he could never align himself with the more extreme Calvinist wing and was always keen to associate with kindred spirits in the wider Christian community. His theology was above all that of personal piety and a personal love relationship with God. His theology was therefore also fundamentally in variance with the liberal and critical spirit of the (then) modern philosophical theology that undermined many of the accepted evangelical postulates (see Brümmer 2013), and he (as moderator) became active in the actions against some such ministers of the DRC.

As he grew older he became more and more profoundly mystical, and a man of prayer. He was deeply involved in 
the spiritual revival which swept through the church in the 1860s, and was in the position to give wise leadership to the movement, also in his official position as moderator of synod (Van der Merwe 1936:155-156). He regarded mission as the main activity of the church, and was deeply involved ecumenically as member and chairman of mission organisations like the South African General Mission and the Sudan United Mission. Through these contacts he was in the position to link up the Lovedale training institute with the need for missionaries at Lake Malawi. He was a prolific writer and became well known internationally through his many writings on the deeper Christian life, prayer and missions (in total some 250 books and tracts).

His passion for Christian missions was intense and he was involved in a number of initiatives. In 1857 he was appointed a member of the first mission committee of the DRC and was instrumental in the decision of the church to commence with a mission project outside the colony (which then meant the Trans-Orange). Whilst searching for mission candidates abroad (Crafford 1982:61) he seriously considered the possibility of making himself available for that task (Maree 1962:16). In 1862 he himself accompanied the first candidate, Alexander McKidd (another Scotsman), to the Soutpansberg in northern Transvaal. (By the way, this McKidd [who unfortunately died too soon] was followed up by Stephanus Hofmeyr [of the Murray clan].)

Whilst he served in Wellington he started the Mission Institute for the training of missionaries (in 1877). It was a private initiative, and was only accepted officially by the church 3 years later, and only taken over in 1903.

Enough is said about the profound influence that this (Scottish) family had on the commendable missionary outreach of the DRC. It is not too farfetched to regard the spirituality which was exemplified by this family as representative of the missionary wing of the South African church in general. If this family supplied an extra-ordinary proportion of the missionary personnel and leadership to the outreaches of the DRC, it is also true that their example and spiritual influence penetrated far further into South African Christian life as a whole. It is this spirit which still permeates the evangelical missionary enterprise.

\section{A common spirituality}

I do think there are commonalities between the few examples of southern African Scottish connections. The following - already delineated - can be mentioned and illustrated through the work of David Livingstone, the Lovedale missionaries, and the Murrays:

- They were never 'mainline', but often represented an alternative mentality and vision. Livingstone broke with the settled mentality of also his father in law, and blazed a new trail. The Missionaries in the Eastern Cape banked on quality education, when a focus on literacy was not even general. The Murrays sided for a pious personal relationship with God over against the newer liberal philosophic theology on the one hand and the ideological confessional theology on the other.

- They were all (to greater or lesser extent) characterised by a simplicity of faith, keeping to the basics. They were strong leaders, often hard headed, but could also lead through example. People realised that they could be trusted, and could be followed. It did not always go well, and they had their detractors, but often they were resented because 'the highest trees catch the most wind'.

- When they tackled something which they felt led by God to do they did not easily let go. They had the courage and tenacity to sail against the wind. Andrew Murray started a training school for missionaries out of his own pocket, even if it took years for the church to accept it and to fund it. Livingstone sacrificed his family to continue with his ever widening outreaches.

- These Scots had a pioneer spirituality. The gospel had to get out to the ends of the earth! The older Andrew Murray was willing to offer a serious compromise to open the way for 'mission among the heathen'. His children and grandchildren opened up vast new mission fields in Africa. Nothing further needs to be said about the impact of Livingstone's travels and communications. The missionaries at Lovedale were obsessed with forming young black people who would be able to give leadership to the church in Africa, and to reach out to the unreached.

- Books and learning were second nature to these 19th century missionaries. Schools and literacy were important to them, and they wrote books to educate the wider public. Not only at Lovedale, but a string of schools, colleges and other institutions were founded by Andrew Murray the younger. Some of those are still leading institutions.

- It was not for them - any of them - to narrow the gospel only to 'spiritual' things. It had to penetrate the whole life of the individual and society. This would naturally involve them in the politics of the day, whether it was colonial policies or church politics. David Livingstone became involved in one of the thorniest issues of the day, namely the abolition of slavery and the trade in humans. The Lovedale missionaries worked for higher education for the black people when it was still frowned upon. The wider Murray family threw in their lot with the Afrikaners even against the might of the British Empire, and also gave immense impetus to the (often unpopular) mission outreach to the marginalised black people of southern Africa. These Scots would not back off from the structural issues touching on the socio-economic needs of the people around them. Their faith, and their calling, was holistic.

\section{A golden thread of a particular missionary spirituality?}

I wanted to trace a possible genealogy of missionary spirituality. I think that, without the exact DNA test that biological genealogists could use, we have seen enough to say that the point has been made. It seems as if the same kind of spirit that 'forced' the early Celtic missionaries to make 
such a huge difference to their world in their time was also working in the 19th century missionaries from Scotland. Whether this drive was coupled with a national (Celtic) mentality, or that it may just have been the same (Holy) Spirit, could be debated, but there are enough traits in common to let one wonder.

It goes without saying that the same missionary spirituality would find expression in very different ways in the early and later centuries with its different contexts.

Bosch (1980:112-113) was of the opinion that the monastic tradition was the most creative response of the early church to the chaos and barbarism of the centuries-long European Dark Ages. 'The disciplined and tireless life of the monks turned the tide of barbarism in Western Europe'. He also quotes the well-known paragraph of Newman:

... Silent men were observed about the country, or discovered in the forest, digging, clearing, and building; and other silent men, not seen, were sitting in the cold cloister, tiring their eyes and keeping their attention on the stretch, while they painfully copied and recopied the manuscripts which they had saved. There was no one who contended or cried out, or drew attention to what was going on, but by degrees the woody swamp became a hermitage, a religious house, a farm, an abbey, a village, a seminary, a school of learning and a city ... (pp. 112-113)

Cahill (1995) adds:

Wherever they went the Irish brought with them their books, many unseen in Europe for centuries and tied to their waist as signs of triumph, just as Irish heroes had once tied to their waist their enemies' heads. Wherever they went they brought their love of learning and their skills in bookmaking ... And that is how the Irish saved civilization. (p. 196)

Their devotion found expression in their monastic life, but not only in a settled monastery (the so-called 'white martyrdom'), but also in the 'green martyrdom' of penance, by moving out of the comfort zone into the unknown and dangerous world out there ... a kind of 'pilgrimage for Christ' (Mellis 1976:23). Bosch (1980:112) quotes Walker who put it as follows: '... the Celtic urge to travel was turned into Christian channels, so that pilgrimage became associated with mission, and both were subordinate to the spiritual perfection of the monk'. Many of them therefore also suffered the inevitable 'red martyrdom' of literally giving their lives for Christ.

The (Irish) monks planted monasteries far and wide, and for centuries these became the centres of culture and civilisation, but also of mission (Bosch 1991:230). These monastic communities were not necessarily intentionally missionary, 'but they were permeated by a missionary dimension' (Bosch 1991:233). This they accomplished through their hard work, their exemplary lifestyle (Columbanus is said to have commented that 'he who believes in Christ ought to walk as Christ walked, poor and humble and always preaching the truth'), disciplined moral activity and their perseverance, their 'spirituality of the long haul' (Bosch 1991:232).

The 19th century Scottish spiritual descendants of these monks lived and served in a totally different world. We looked at a few who came to the southern end of Africa, a continent vastly different from Europe. The African communities that they went to had no Christian history, but were bleeding from the colonial (and pre-colonial) exploitation, and the tension between the (few) Christians and the larger number of preChristians. Much of Africa was unknown, as well as the plight of the people. Into this situation Livingstone moved. He discovered 'the open sore' of the slave trade, and tirelessly trekked through the sub-continent to do what he could to eradicate it through (as he formulated it) 'Christianity, civilization and commerce'. Into an established church in the Cape moved Andrew Murray and did what he could to instil a missionary spirit into the Christian community in order for them to reach out into the then 'dark Africa'. Into an illiterate Xhosa community moved the missionaries of Lovedale and gave them the best they could: a Christian upbringing for the youth, coupled with thorough learning and skills for the new world that is waiting.

This asked for just an adventurous, ascetic and pious spirituality as in the days of old.

\section{Acknowledgements Competing interests}

The author declares that he has no financial or personal relationship(s) which may have inappropriately influenced him in writing this article.

\section{References}

Adonis, J.C., 1982, Die afgebreekte skeidsmuur weer opgebou, Rodopi, Amsterdam.

Bavinck, J.H., 1948, Zending in een Wereld in Nood, NV Gebr. Zomer en Keuning's Uitgeversmaatschappij, Wageningen.

Bosch, D.J., 1979, A spirituality of the road, Herald Press, Scottdale.

Bosch, D.J., 1980, Witness to the world: The Christian mission in theological perspective, John Knox Press, Atlanta.

Bosch, D.J., 1991, Transforming mission: Paradigm shifts in theology of mission, Orbis Books, Maryknoll.

Brümmer, V., 2013, Vroom of regsinnig: Teologie in die NG Kerk, Bybel-Media, Wellington.

Cahill, T., 1995, How the Irish saved civilization?: The untold story of Ireland's heroic role from the fall of Rome to the rise of medieval Europe, Doubleday, New York.

Crafford, D., 1982, Aan God die Dank. Geskiedenis van die sending van die Ned Geref Kerk binne die Republiek van Suid-Afrika en enkele aangrensende Buurstate, NGKB, Pretoria.

Cronjé, J.M., 1948, En daar was Lig: Die sending van die Ned Geref Kerk in die OVS in Noord-en Suid-Rhodesië, gedurende die jare 1899-1949, SSK, Bloemfontein.

Cronjé, J.M., 1981, Aan God die dank. Deel 2: Geskiedenis van die sending van die Ned Geref Kerk buite die Republiek van Suid-Afrika, NGKB, Pretoria.

Duncan, G.A., 2004, 'Coercive agency in mission education at Lovedale Missionary Institution', HTS Teologiese Studies/Theological Studies 60(3), 947-992.

Du Plessis, J., [1911] 1965, A history of Christian missions in South Africa, Struik, Cape Town.

Du Plessis, J., 1912, The evangel in South Africa, Missionary Exhibition, Cape Town. Horne, C.S., 1894, The story of the LMS, 1795-1895, LMS, London.

Maree, W.L., 1962, Lig in die Soutpansberg: Die sendingwerk van die Nederduitse Gereformeerde Kerk in Noord-Transvaal 1863-1963, NGKB, Pretoria.

Mellis, C.J., 1976, Committed communities: Fresh streams for world missions, William Carey Library, Pasadena.

Neill, S., 1964, A History of Christian missions, Penguin Books, London.

Ransford, O., 1966, Livingstone's lake: The drama of Nyasa, John Murray, London.

Van den Berg, J., 1965, 'Een open pad voor handel en Christendom: David Livingstone's inzichten betreffende de introductie van "commerce" en "Christianity" in Afrika', in J. van den Berg (ed.), Christusprediking in de Wereld, Studiën op het terrein van de Zendingswetenschap gewijd aan de nagedachtenis van Professor Dr Johan Herman Bavinck, pp. 63-90, JH Kok, Kampen.

Van der Merwe, W.J., 1936, The development of missionary attitudes in the Dutch Reformed Church in South Africa, Nasionale Pers, Cape Town. 